\title{
Physico-Chemical and Bacterial Characteristics of Groundwater and Surface Water Quality in the Lagbe Town: Treatment Essays with Moringa oleifera Seeds
}

\author{
K. Jacques Fatombi ${ }^{1 *}$, T. Angèle Ahoyo ${ }^{2}$, Odilon Nonfodji ${ }^{1,2}$, Taofiki Aminou ${ }^{1}$ \\ ${ }^{1}$ Laboratoire d'Expertise et de Recherche en Chimie de l'Eau et de l'Environnement (LERCEE), \\ Faculté des Sciences et Techniques, Université d'Abomey-Calavi, Cotonou, Bénin \\ ${ }^{2}$ Laboratoire de Diagnostique et d'Analyses Biomédicales (DIMED), Ecole Polytechnique d'Abomey-Calavi, Cotonou, Bénin

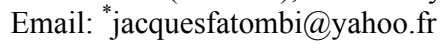

Received September 21, 2012; revised October 29, 2012; accepted November 9, 2012

\begin{abstract}
The river water and groundwater from Lagbe town in Benin Republic were collected and analyzed for physical, chemical and microbiological parameters. The surface water samples were treated with alum, Moringa oleifera seeds powder and the combination of alum and Moringa oleifera seeds. The jar-test essays were carried out with two water samples at initial turbidities 7.2 NTU and 14.4 NTU. The water samples analyzed are fairly mineralized (conductivity varies between 166 and $687 \mu \mathrm{S} / \mathrm{cm})$, enough soft and contain the nitrate $\left(104 \mathrm{mg} / \mathrm{L}\right.$ for $\mathrm{W}_{4}$ sample). They are greatly polluted by pathogenic microorganisms such as Escherichia coli, Klebsiella, Enterococcus, Vibrio, Serratia. The optimal dosages of Moringa are $96 \mathrm{mg} / \mathrm{L}$ and $80 \mathrm{mg} / \mathrm{L}$ respectively. We have observed a reduction of $60 \%$ of turbidity and a substantial remove of all pathogenic microorganisms after water treatment with Moringa oleifera seeds. For the combination treatment, $93 \%$ of initial turbidity and $92 \%$ of initial concentration of organic matter in the sample $E_{2}$ were eliminated. The $\mathrm{pH}$ remained almost constant during the treatment.
\end{abstract}

Keywords: Groundwater; Surface Water; Moringa oleifera; Water Treatment; Physic; Chemical; Bacterial Characteristics

\section{Introduction}

Water is an indispensable natural resource for life on earth. Potable drinking water is the primary need of every human being. Groundwater and the surface water are the major source of drinking water in both urban and rural areas [1,2]. Man uses water for domestic, agricultural, social and industrial purposes. The increase of the population and its needs have led to the deterioration of surface and sub surface water [3].

In Benin Republic, the rate of effective access to drinking water in rural and semi urban areas is $41 \%$ at 2005. In the Lagbe, a rural district, the people do not have access to the drinking water network. They drink the untreated groundwater and the surface water. The World Health Organization estimated that up to $80 \%$ of all sicknesses and diseases in the world are caused by inadequate sanitation, polluted water or unavailability of water [4]. The treatment processes cover three major operations: coagulation/flocculation, sedimentation and filtration disinfection. The natural polyelectrolytes of plant origin have been used for many centuries in devel${ }^{*}$ Corresponding author. oping countries for clarifying turbid water. Even under such conditions, a few plant seeds make effective coagulants [5] for water treatment as compared to those of alum. In laboratory and field studies, Moringa oleifera seeds extract has shown promise as natural flocculant and coagulant that aid in binding the solids in turbid water [6-10].

In the present study, the determination of physicochemical and bacterial characteristics of groundwater and surface water quality in the study area and the performance of aqueous extract of Moringa oleifera seeds as primary coagulant and as coagulant aid with alum in treatment of surface water samples was examined and compared with the performance of alum used alone.

\section{Materials and Methods}

\subsection{Study Area}

Lagbe town is located at 6 $6^{\circ} 40^{\prime} 34.91 "$ North latitude and $2^{\circ} 42^{\prime} 2.76^{\prime \prime}$ East longitude in Ifangni District. The present study was planned by selecting two different sites around Lagbe area which included two villages Zihan and Lagbe 
Center. The literature survey showed that no groundwater and surface water studies were made in these regions so far. Hence the present study was undertaken.

\subsection{Collection of Water Samples}

The groundwater and the surface water samples were collected in borosilicate glassware of $500 \mathrm{~mL}$ capacity according to the standard procedure NF EN 25667-1 [11]. For the bacteriological analysis, the bottles were sterilized in autoclave at $120^{\circ} \mathrm{C}$ for $1 \mathrm{~h}$, after which, the sample was added. For physico-chemical analysis, the sample bottles were rinsed with distilled water and later with water of the sample. Water samples from seven (07) sampling points of groundwater and seven (07) points of surface water situated at different location were collected during six months (August 2011 to February 2012). The water samples were named as well as samples $1\left(\mathrm{~W}_{1}\right), \cdots$, samples $7\left(\mathrm{~W}_{7}\right)$, and surface samples $1\left(\mathrm{~S}_{1}\right), \cdots$ samples 7 $\left(\mathrm{S}_{7}\right)$. The sampling points data are represented on Table 1. The samples were carried to the laboratory at $4^{\circ} \mathrm{C}$ in icebox and kept in refrigerator maintained at $4^{\circ} \mathrm{C}$. The parameters such as temperature, initial turbidity, $\mathrm{pH}$, conductivity and dissolved oxygen were measured in the field study.

\subsection{Preparation of Coagulants}

\subsubsection{Moringa oleifera}

Moringa oleifera seeds used in this study were collected from Zihan. After shelling, the mature dry seeds are crushed in mortar laboratory with pestle and sieved (using $0.8 \mathrm{~mm}$ mesh). $2 \mathrm{~g}$ of the powder were dispersed in $100 \mathrm{~mL}$ of distilled water. The suspension was stirred during 1 hour and settled during 1 hour. The collected supernatant was filtered through Wattman pleated filter

Table 1. Location of sampling points.

\begin{tabular}{cccc}
\hline $\begin{array}{c}\text { Groundwater } \\
\text { samples }\end{array}$ & $\begin{array}{c}\text { Geographical } \\
\text { coordinates }\end{array}$ & $\begin{array}{c}\text { Surface } \\
\text { water } \\
\text { samples }\end{array}$ & $\begin{array}{c}\text { Geographical } \\
\text { coordinates }\end{array}$ \\
\hline $\mathrm{W}_{1}$ & $6^{\circ} 41^{\prime} 10.0^{\prime \prime} \mathrm{N}$ & $\mathrm{S}_{1}$ & $6^{\circ} 41^{\prime} 05.8^{\prime \prime} \mathrm{N}$ \\
& $2^{\circ} 40^{\prime} 32.6^{\prime \prime} \mathrm{E}$ & & $2^{\circ} 40^{\prime} 43.8^{\prime \prime} \mathrm{E}$ \\
$\mathrm{W}_{2}$ & $6^{\circ} 41^{\prime} 01.5^{\prime \prime} \mathrm{N}$ & $\mathrm{S}_{2}$ & $6^{\circ} 40^{\prime} 42.3^{\prime \prime} \mathrm{N}$ \\
& $2^{\circ} 40^{\prime} 21.5^{\prime \prime} \mathrm{E}$ & & $2^{\circ} 41^{\prime} 56.8^{\prime \prime} \mathrm{E}$ \\
$\mathrm{W}_{3}$ & $6^{\circ} 41^{\prime} 15.3^{\prime \prime} \mathrm{N}$ & $\mathrm{S}_{3}$ & $6^{\circ} 41^{\prime} 19.2^{\prime \prime} \mathrm{N}$ \\
& $2^{\circ} 40^{\prime} 22.7^{\prime \prime} \mathrm{E}$ & & $6^{\circ} 40^{\prime} 50.4^{\prime \prime} \mathrm{E}$ \\
$\mathrm{W}_{4}$ & $6^{\circ} 41^{\prime} 19.6 \mathrm{\prime} \mathrm{N}$ & $\mathrm{S}_{4}$ & $2^{\circ} 40^{\prime} 50.4^{\prime \prime} \mathrm{N}$ \\
& $2^{\circ} 40^{\prime} 14.7^{\prime \prime} \mathrm{E}$ & & $6^{\circ} 41^{\prime} 17.6^{\prime \prime} \mathrm{N}$ \\
$\mathrm{W}_{5}$ & $6^{\circ} 40^{\prime} 35.5^{\prime \prime} \mathrm{N}$ & $\mathrm{S}_{5}$ & $2^{\circ} 40^{\prime} 53.6^{\prime \prime} \mathrm{E}$ \\
& $2^{\circ} 40^{\prime} 04.3^{\prime \prime} \mathrm{E}$ & & $6^{\circ} 41^{\prime} 19.5^{\prime \prime} \mathrm{N}$ \\
$\mathrm{W}_{6}$ & $6^{\circ} 41^{\prime} 24.2^{\prime \prime} \mathrm{N}$ & $\mathrm{S}_{6}$ & $2^{\circ} 40^{\prime} 57.8^{\prime \prime} \mathrm{E}$ \\
& $2^{\circ} 40^{\prime} 13.0^{\prime \prime} \mathrm{E}$ & & $6^{\circ} 40^{\prime} 56.1^{\prime \prime} \mathrm{N}$ \\
$6^{\circ} 41^{\prime} 20.5^{\prime \prime} \mathrm{N}$ & & $\mathrm{S}_{7}$ & $2^{\circ} 41^{\prime} 43.3^{\prime \prime} \mathrm{E}$ \\
\hline
\end{tabular}

paper and the collected filtrate is used as a coagulant. The removed residues were oven-dried at $45^{\circ} \mathrm{C}$ until constant weight. The amount of dissolved Moringa in filtrate was calculated from the difference between the mass of Moringa dispersed in distilled water ( $2 \mathrm{~g})$ and dried residue.

\subsubsection{Aluminum Sulphate}

About $5 \mathrm{~g}$ of aluminum sulphate which formula is $\left(\mathrm{Al}_{2}\left(\mathrm{SO}_{4}\right)_{3} \cdot 18 \mathrm{H}_{2} \mathrm{O}\right)$ were dissolved in $250 \mathrm{~mL}$ of distilled water. The obtain- ed solution is used as coagulant.

\subsection{Jar-Test Essays Procedure}

Jar-test essays were carried out in a $1000 \mathrm{~mL}$ glass beaker with the water surface samples having the initial turbidities of 14.4 and 7.2 Nephelometric Turbidity Unit (NTU). The increased volume of aqueous extract of Moringa or of alum solution was then added in $500 \mathrm{~mL}$ of raw water with a micropipette $(500 \mu \mathrm{L})$. The mixture was stirred with the rectangular pale of numeric flocculator Fisher Broslock Scientific. The stirring rate was maintained at $200 \mathrm{trs} / \mathrm{min}$ for $3 \mathrm{~min}$ and slowed down at $50 \mathrm{trs} / \mathrm{min}$ for $25 \mathrm{~min}$. At the end of stirring, the aggregated suspension was settled during 2 hours. A volume of $100 \mathrm{~mL}$ of supernatant was siphoned. In this sample, the residual turbidity, $\mathrm{pH}$, oxydisability with potassium permanganate and microbiological parameters were measured. The coagulation activity was calculated based on Lee's equation [12].

Coagulation activity $=100(\mathrm{To}-\mathrm{Tr}) / \mathrm{To}$ with $\mathrm{To}=$ initial turbidity and $\mathrm{Tr}=$ residual turbidity.

\subsection{Physico-Chemical and Microbiological Analysis}

The $\mathrm{pH}$, dissolved oxygen, conductivity and residual turbidity were measured with (WTW) multimeter and HANNA turbidimeter. The total alkalinities of the water samples were determined by titrating with $\mathrm{N} / 50 \quad \mathrm{H}_{2} \mathrm{SO}_{4}$ using phenolphthalein and methyl orange as indicators. The total hardness of the water samples was measured by complexometric titration with EDTA using Erichrome black $\mathrm{T}$ as an indicator. The organic matters contained in the water sample were measured by oxydisability with potassium permanganate. The anions (fluoride $\mathrm{F}^{-}$, chloride $\mathrm{Cl}^{-}$, nitrate $\mathrm{NO}_{3}^{-}$, nitrite $\mathrm{NO}_{2}^{-}$, phosphate $\mathrm{PO}_{4}^{3-}$ and sulphate $\mathrm{SO}_{4}^{2-}$ ) were measured by Dionex ICS 10001 ionic chromatograph.

The microorganisms (Escherichia coli, Klebsiella spp, Vibrio cholerae, Enterococcus spp, Serratia spp, Aeromonas spp, Asppergillus spp) were identified according to [13]. The results obtained were processed and analyzed using SPSS 10.1. The different proportions were compared by $X^{2}$ test or Fischer at significance level of 0.05 . 


\section{Results and Discussion}

\subsection{Physico-Chemical and Bacteriological Characteristics of Groundwater and Surface Water}

The collected samples were analyzed. The analysis (Tables 2 and 3) of groundwater and surface water samples includes the determination of physico-chemical parameters. The bacteriological characteristics of samples are shown in Tables $\mathbf{4}$ and $\mathbf{5}$.

The desirable $\mathrm{pH}$ suitable for drinking water is between 6.5 and 8.5 [4]. The $\mathrm{pH}$ values of water samples in the study area ranged from 4.6 to 5.8 , this is under the prescribed standard value for drinking water. This shows

Table 2. Physico-chemical characteristics of well water.

\begin{tabular}{|c|c|c|c|c|c|c|c|}
\hline \multirow{2}{*}{ Parameters } & \multicolumn{7}{|c|}{ Samples } \\
\hline & $\mathrm{W}_{1}$ & $\mathrm{~W}_{2}$ & $\mathrm{~W}_{3}$ & $\mathrm{~W}_{4}$ & $\mathrm{~W}_{5}$ & $\mathrm{~W}_{6}$ & $\mathrm{~W}_{7}$ \\
\hline Dissolved oxygen (mg/L) & $3.4 \pm 0.10$ & $2.5 \pm 0.10$ & $3.8 \pm 0.10$ & $3.9 \pm 0.10$ & $3.3 \pm 0.10$ & $3.8 \pm 0.10$ & $3.3 \pm 0.10$ \\
\hline Conductivity ( $\mu \mathrm{S} / \mathrm{cm})$ & $282.5 \pm 8$ & $237 \pm 8$ & $267.5 \pm 8$ & $687 \pm 10$ & $556 \pm 10$ & $530 \pm 10$ & $194 \pm 8$ \\
\hline Turbidity (NTU) & $1.7 \pm 0.2$ & $2.0 \pm 0.2$ & $2.2 \pm 0.2$ & $0.7 \pm 0.1$ & $2.2 \pm 0.2$ & $2.0 \pm 0.2$ & $1.0 \pm 0.1$ \\
\hline Alkalinity $\left({ }^{\circ} \mathrm{F}\right)$ & $4.80 \pm 0.20$ & $4.90 \pm 0.20$ & $4.75 \pm 0.20$ & $4.70 \pm 0.20$ & $4.18 \pm 0.20$ & $4.23 \pm 0.20$ & $4.00 \pm 0.20$ \\
\hline Total hardness $\left({ }^{\circ} \mathrm{F}\right)$ & $2.35 \pm 0.10$ & $2.10 \pm 0.10$ & $3.30 \pm 0.10$ & $6.50 \pm 0.10$ & $5.90 \pm 0.10$ & $6.50 \pm 0.10$ & $3.00 \pm 0.10$ \\
\hline Organic matter (mg/L) & $1.49 \pm 0.10$ & $2.83 \pm 0.10$ & $1.42 \pm 0.10$ & $1.65 \pm 0.10$ & $2.76 \pm 0.10$ & $1.35 \pm 0.10$ & $1.78 \pm 0.10$ \\
\hline $\mathrm{NO}_{2}^{-} \quad(\mathrm{mg} / \mathrm{L})$ & $0.57 \pm 0.10$ & $0.64 \pm 0.10$ & $1.85 \pm 0.10$ & $0.90 \pm 0.10$ & $0.60 \pm 0.10$ & $0.56 \pm 0.10$ & $0.59 \pm 0.10$ \\
\hline $\mathrm{Cl}^{-}(\mathrm{mg} / \mathrm{L})$ & $28.89 \pm 1.50$ & $27.60 \pm 1.50$ & $31.93 \pm 1.50$ & $42.8 \pm 1.50$ & $32.6 \pm 1.50$ & $33.72 \pm 1.50$ & $21.3 \pm 1.50$ \\
\hline $\mathrm{PO}_{4}^{3-} \quad(\mathrm{mg} / \mathrm{L})$ & $0.12 \pm 0.05$ & $0.25 \pm 0.05$ & $0.30 \pm 0.05$ & $0.30 \pm 0.05$ & $0.20 \pm 0.05$ & $0.35 \pm 0.05$ & $0.70 \pm 0.05$ \\
\hline $\mathrm{SO}_{4}^{2-} \quad(\mathrm{mg} / \mathrm{L})$ & $1.00 \pm 0.10$ & $1.00 \pm 0.10$ & $1.50 \pm 0.10$ & $0.50 \pm 0.10$ & $6.50 \pm 0.10$ & $1.00 \pm 0.10$ & $5.00 \pm 0.10$ \\
\hline
\end{tabular}

Table 3. Physico-chemical characteristics of surface waters.

\begin{tabular}{|c|c|c|c|c|c|c|c|}
\hline \multirow{2}{*}{ Parameters } & \multicolumn{7}{|c|}{ Samples } \\
\hline & $\mathrm{S}_{1}$ & $\mathrm{~S}_{2}$ & $\mathrm{~S}_{3}$ & $\mathrm{~S}_{4}$ & $\mathrm{~S}_{5}$ & $\mathrm{~S}_{6}$ & $\mathrm{~S}_{7}$ \\
\hline $\mathbf{p H}$ & $4.6 \pm 0.2$ & $4.8 \pm 0.2$ & $4.9 \pm 0.2$ & $5.0 \pm 0.2$ & $5.1 \pm 0.2$ & $5.8 \pm 0.2$ & $5.9 \pm 0.2$ \\
\hline Dissolved oxygen (mg/L) & $3.20 \pm 0.10$ & $3.30 \pm 0.10$ & $3.00 \pm 0.10$ & $3.10 \pm 0.10$ & $3.30 \pm 0.10$ & $3.00 \pm 0.10$ & $3.30 \pm 0.10$ \\
\hline Turbidity (NTU) & $0.4 \pm 0.1$ & $0.6 \pm 0.1$ & $5.6 \pm 0.5$ & $4.6 \pm 0.5$ & $7.0 \pm 0.50$ & $7.8 \pm 0.50$ & $10.7 \pm 0.50$ \\
\hline Alkalinity $\left({ }^{\circ} \mathrm{F}\right)$ & $4.00 \pm 0.20$ & $3.30 \pm 0.20$ & $3.40 \pm 0.20$ & $3.20 \pm 0.20$ & $3.60 \pm 0.20$ & $3.50 \pm 0.20$ & $3.50 \pm 0.20$ \\
\hline Total hardness $\left({ }^{\circ} \mathrm{F}\right)$ & $2.40 \pm 0.10$ & $2.10 \pm 0.10$ & $1.90 \pm 0.10$ & $1.90 \pm 0.10$ & $3.40 \pm 0.10$ & $2.00 \pm 0.10$ & $2.10 \pm 0.10$ \\
\hline Organic matter (mg/L) & $0.50 \pm 0.10$ & $4.00 \pm 1.20$ & $4.40 \pm 1.20$ & $4.40 \pm 1.20$ & $3.50 \pm 1.20$ & $12.50 \pm 2.50$ & $12,87 \pm 2.50$ \\
\hline $\mathrm{NO}_{3}^{-} \quad(\mathrm{mg} / \mathrm{L})$ & $25.66 \pm 2.50$ & $23.17 \pm 2.50$ & $23 \pm 2.50$ & $28 \pm 2.50$ & $33 \pm 2.50$ & $1.30 \pm 0.60$ & $1.40 \pm 0.60$ \\
\hline $\mathrm{NO}_{2}^{-}(\mathrm{mg} / \mathrm{L})$ & $0.4 \pm 0.10$ & $0.4 \pm 0.10$ & $0.5 \pm 0.10$ & $0.35 \pm 0.10$ & $0.40 \pm 0.10$ & $0.15 \pm 0.10$ & $0.20 \pm 0.10$ \\
\hline $\mathrm{Cl}^{-}(\mathrm{mg} / \mathrm{L})$ & $41.3 \pm 1.50$ & $35.12 \pm 1.50$ & $29 \pm 0.50$ & $28.50 \pm 0.50$ & $36.23 \pm 1.50$ & $27 \pm 0.50$ & $27.5 \pm 0.50$ \\
\hline $\mathrm{PO}_{4}^{3-} \quad(\mathrm{mg} / \mathrm{L})$ & $0.24 \pm 0.05$ & $0.10 \pm 0.05$ & $0.32 \pm 0.05$ & $0.14 \pm 0.05$ & $0.14 \pm 0.05$ & $0.24 \pm 0.05$ & $0.26 \pm 0.05$ \\
\hline $\mathrm{SO}_{4}^{2-} \quad(\mathrm{mg} / \mathrm{L})$ & $0.20 \pm 0.10$ & $0.20 \pm 0.10$ & $0.20 \pm 0.10$ & $0.50 \pm 0.10$ & $0.20 \pm 0.10$ & $0.50 \pm 0.10$ & $0.50 \pm 0.10$ \\
\hline
\end{tabular}


Table 4. Microbiological characteristics of groundwater.

\begin{tabular}{ccccccccc}
\hline Parameters & \multicolumn{9}{c}{ Samples } \\
\cline { 2 - 8 } & $\mathrm{W}_{1}$ & $\mathrm{~W}_{2}$ & $\mathrm{~W}_{3}$ & $\mathrm{~W}_{4}$ & $\mathrm{~W}_{5}$ & $\mathrm{~W}_{6}$ & $\mathrm{~W}_{7}$ \\
\hline Escherichia coli (UFC/mL) & 192,000 & 256,000 & 128,000 & 192,000 & 256,000 & 64,000 & 64,000 \\
Klebsiella spp (UFC/mL) & 0 & 320,000 & 0 & 320,000 & 320,000 & 192,000 & 128,000 \\
Enterococus spp (UFC/mL) & 1600 & 0 & 0 & 32,000 & 0 & 0 & 0 & 0 \\
Serratia spp (UFC/mL) & 128,000 & 192,000 & 0 & 128,000 & 0 & 0 & 0 \\
Aéromonas spp (UFC/mL & 192,000 & 256,000 & 0 & 0 & 0 & 0 & 0 \\
Asppergillus spp (UFC/mL) & 0 & 0 & 0 & 32,000 & 0 & 0 & 0 \\
\hline
\end{tabular}

Table 5. Microbiological characteristics of surface waters.

\begin{tabular}{cccccccc}
\hline \multirow{2}{*}{ Parameters } & \multicolumn{7}{c}{ Samples } \\
\cline { 2 - 8 } & $\mathrm{S}_{1}$ & $\mathrm{~S}_{2}$ & $\mathrm{~S}_{3}$ & $\mathrm{~S}_{4}$ & $\mathrm{~S}_{5}$ & $\mathrm{~S}_{6}$ & $\mathrm{~S}_{7}$ \\
\hline Escherichia coli (UFC/mL) & 28,000 & 320,000 & 320,000 & 116,000 & 320,000 & 256,000 & 320,000 \\
Klebsiella spp (UFC/mL) & 0 & 160,000 & 0 & 98,000 & 0 & 320,000 & 320,000 \\
Vibrio cholerae (UFC/mL) & 0 & 8000 & 0 & 0 & 16,000 & 32,000 & 32,000 \\
Enterococus spp (UFC/mL) & 0 & 3200 & 32,000 & 0 & 0 & 4800 & 4800 \\
Serratia spp (UFC/mL) & 64,000 & 64,000 & 128,000 & 0 & 128,000 & 320,000 & 192,000 \\
\hline
\end{tabular}

that $\mathrm{pH}$ of water sample was acidic. Total alkalinity of water varied from $4.18^{\circ} \mathrm{F}$ to $4.90^{\circ} \mathrm{F}$ for groundwater and $3.20^{\circ} \mathrm{F}$ to $4.00^{\circ} \mathrm{F}$ for surface water. The values of total alkalinity were comparatively moderate. Total hardness measured was found in the water samples in the ranges of $2.10^{\circ} \mathrm{F}$ to $6.50^{\circ} \mathrm{F}$ for groundwater and $1.90^{\circ} \mathrm{F}$ to $3.40^{\circ} \mathrm{F}$ for surface water, which shows that water is very soft $[4,14]$.

Chloride content of the water samples was low. According to WHO standards, maximum acceptable limit for chloride is $500 \mathrm{mg} / \mathrm{L}$. The values observed in the present study are between 21.3 and $42.8 \mathrm{mg} / \mathrm{L}[14,15]$. The sulphate content varies between $0.50 \mathrm{mg} / \mathrm{L}$ and 6.50 $\mathrm{mg} / \mathrm{L}$ for groundwater, $0.20 \mathrm{mg} / \mathrm{L}$ and $0.50 \mathrm{mg} / \mathrm{L}$ for surface water. The specific conductivity of water samples varies between 166 and $687 \mu \mathrm{S} / \mathrm{cm}$. The maximum permissible limit of this parameter for drinking water is 300 $\mu \mathrm{S} / \mathrm{cm}$. However, the average specific conductivity exceeds this limit for wells $\mathrm{W}_{4}(687 \mu \mathrm{S} / \mathrm{cm}), \mathrm{W}_{5}(556$ $\mu \mathrm{S} / \mathrm{cm})$ and $\mathrm{W}_{6}(530 \mu \mathrm{S} / \mathrm{cm})$.

The water samples concentration of dissolved oxygen varies between $2.50 \mathrm{mg} / \mathrm{L}$ and $3.8 \mathrm{mg} / \mathrm{L}$. These values are lower than the maximum recommended limit for dissolved oxygen which is $8 \mathrm{mg} / \mathrm{L}$ [4]. The turbidities of groundwater samples are weak and varies between 1.4 NTU and 2.3 NTU. The turbidities of surface water samples $\left(\mathrm{S}_{1}\right.$ and $\left.\mathrm{S}_{2}\right)$ are also weak and equal to $0.5 \mathrm{NTU}$, but the samples $S_{3}$ to $S_{7}$ are more turbid, they contained more colloidal particles. Indeed, their turbidities varies between 4.6 and 10.7 NTU. The dissolved organic matters of groundwater are weak enough. However the water samples of the wells $\mathrm{W}_{2}$ and $\mathrm{W}_{5}$ contain more organic matters because these wells are not covered. Indeed, the polyethylene buckets used by people to take water could be also source of water enrichment in organic matters as the seal is often in contact with the soil. The dissolved organic matter of surface water was above $3 \mathrm{mg} / \mathrm{L}$ which represented the permissible limit [4] except the sample $\mathrm{W}_{1}$. This water sample was taken probably from a stream.

The concentration of nitrate in the analyzed samples ranges between 21.1 and $102 \mathrm{mg} / \mathrm{L}$ for the well water when it was 1.30 to $28 \mathrm{mg} / \mathrm{L}$ for the surface water. The relatively higher concentration range of $\mathrm{NO}_{3}^{-}$(52 at 102 $\mathrm{mg} / \mathrm{L}$ ) for the wells $\mathrm{W}_{4}, \mathrm{~W}_{5}, \mathrm{~W}_{6}$ and $\mathrm{W}_{7}$ clearly indicates contamination of the waters with domestic waste water or with waste water from leaking septic tanks built near these wells. The concentration of nitrite is weak enough and varies between $0.56 \mathrm{mg} / \mathrm{L}$ and $1.87 \mathrm{mg} / \mathrm{L}$ for the groundwater when it varies from $0.2 \mathrm{mg} / \mathrm{L}$ to $0.4 \mathrm{mg} / \mathrm{L}$ for the surface water. The concentration of sulphates and phosphates in the analyzed samples are very low.

The results shown in Tables $\mathbf{4}$ and $\mathbf{5}$ indicate that the analyzed waters were polluted by various microorganisms such as: Escherichia, Klebsiella, Enterococus, Serratia, Aeromonas, Asppergillus. In the groundwater samples, the number of $E$. coli varies between $64,000 \mathrm{UFC} / \mathrm{mL}$ 
and $256,000 \mathrm{UFC} / \mathrm{mL}$, that of Klebsiella varies from $128,000 \mathrm{UFC} / \mathrm{mL}$ to $320,000 \mathrm{UFC} / \mathrm{mL}$. Those of Enterococcus, Serratias and Aeromonas varies between 1600 $\mathrm{UFC} / \mathrm{mL}$ and $32,000 \mathrm{UFC} / \mathrm{mL}, 128,000 \mathrm{UFC} / \mathrm{mL}$ and $192,000 \mathrm{UFC} / \mathrm{mL}, 192,000 \mathrm{UFC} / \mathrm{mL}$ and $256,000 \mathrm{UFC} / \mathrm{mL}$ respectively. In the surface water samples, the number of $E$. coli, Klebsiella, Vibrio, Enterococcus and Serratia varies between $28000 \mathrm{UFC} / \mathrm{mL}$ and 320,000 UFC/mL, 98,000 $\mathrm{UFC} / \mathrm{mL}$ and $320,000 \mathrm{UFC} / \mathrm{mL}, 8000 \mathrm{UFC} / \mathrm{mL}$ and $32,000 \mathrm{UFC} / \mathrm{mL}, 3200 \mathrm{UFC} / \mathrm{mL}$ and $4800 \mathrm{UFC} / \mathrm{mL}$, $64,000 \mathrm{UFC} / \mathrm{mL}$ and $320,000 \mathrm{UFC} / \mathrm{mL}$ respectively. The consumption of drinking water contaminated with pathogenic microbes of faecal origin has a significant risk on human health in the developing countries, especially in rural and industrial areas [1,16-18]. All analyzed water samples are not potable.

\subsection{Water Treatment}

Two samples $\left(E_{1}\right.$ and $\left.E_{2}\right)$ of River water $S_{7}$ having initial turbidities 14.4 NTU and 7.2 NTU and which the dissolved organic matters were $12.37 \mathrm{mg} / \mathrm{L}$ and $5.60 \mathrm{mg} / \mathrm{L}$ respectively were treated by the aqueous extracts of Moringa. The obtained results were represented on Figures 1 and 2 and the Table 6.

We noticed on the graphs $1 \mathrm{a}$ and $1 \mathrm{~b}$ of Figure 1, that

Table 6. Microbiological characteristics of the treated water by Moringa .

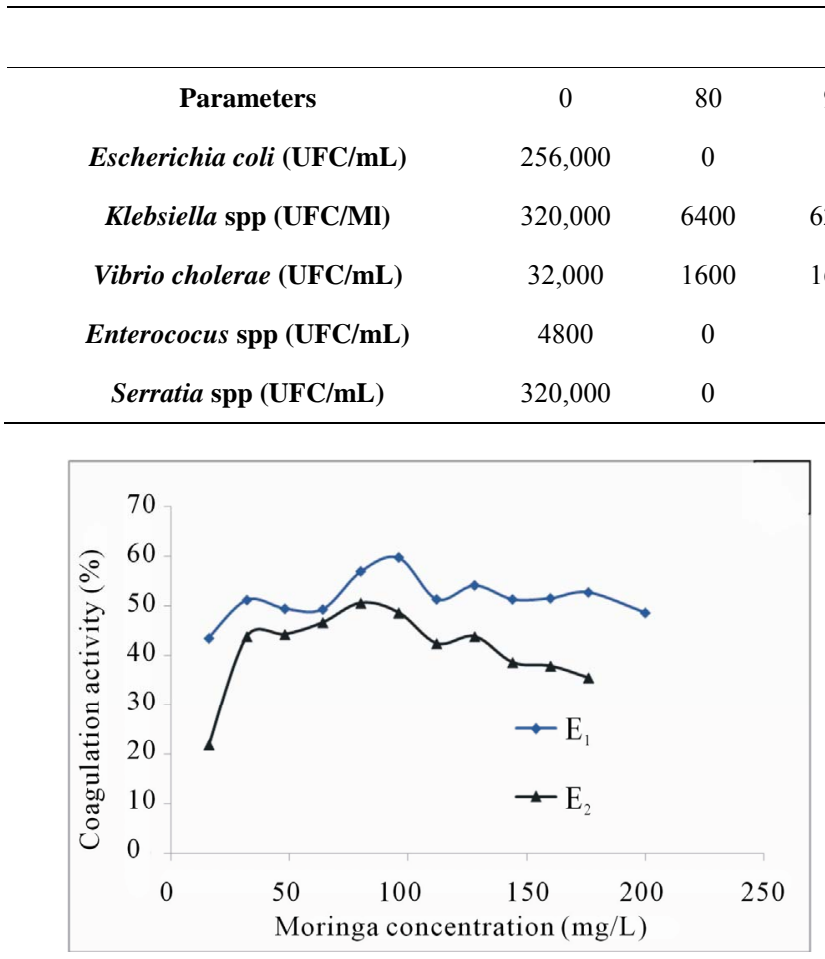

(a)

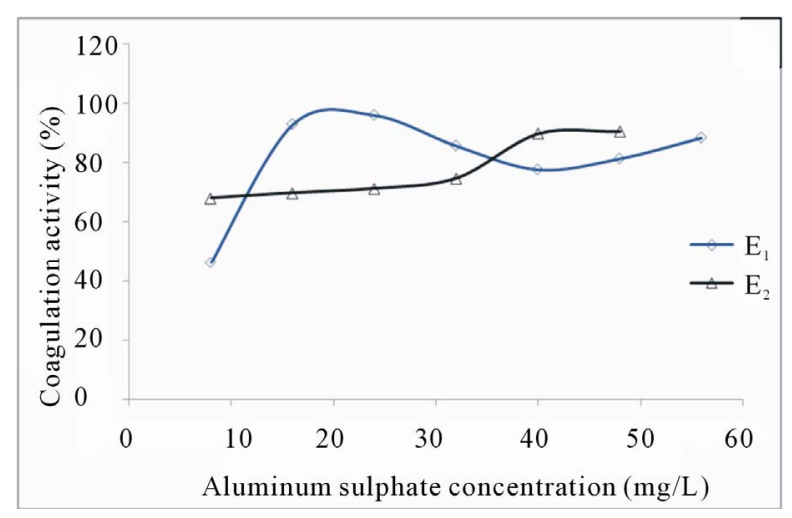

(b)

Figure 1. Variation of coagulation activity as function of coagulant concentration.

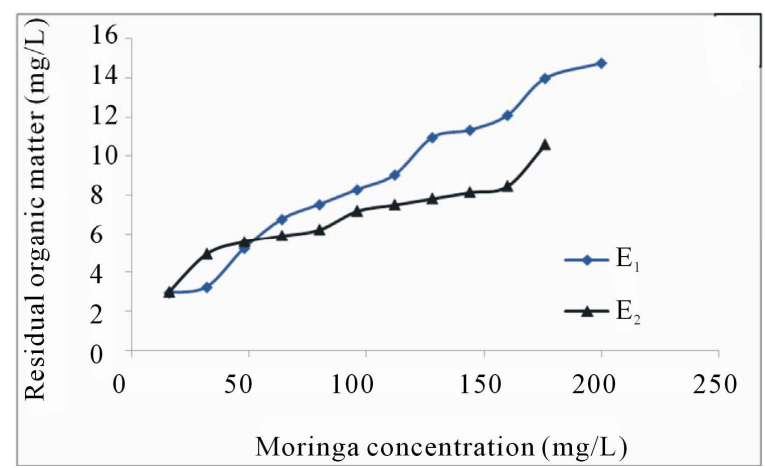

(a)

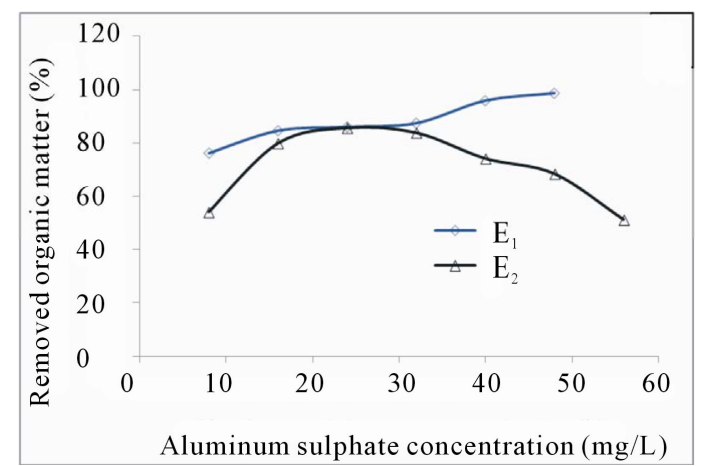

(b)

Figure 2. Variation of organic matter as function of coagulant concentration. 
the rate of turbidity reduction of treated water increase with the concentrations of each coagulant until it has reached a maximum value. The turbidity reduction depends however on the nature of the coagulant used and the initial turbidity of raw water. Turbidity reduction rate was $60 \%$ and $50 \%$ for samples $\mathrm{E}_{1}$ and $\mathrm{E}_{2}$ during the treatment with Moringa oleifera seeds and $88 \%$ and $96 \%$ when using aluminum sulphate. The optimal doses of the coagulants are respectively $96 \mathrm{mg} / \mathrm{L}$ and $80 \mathrm{mg} / \mathrm{L}$ for Moringa then $40 \mathrm{mg} / \mathrm{L}$ and $24 \mathrm{mg} / \mathrm{L}$ for alum.

On the graphs of Figure 2(a), there is an increase of dissolved organic matter in treated water by Moringa oleifera. This enrichment of the treated water by organic matter is proportional to doses of Moringa used. The addition of organic matter rate is $20 \%$ and $89 \%$ for $E_{1}$ and $E_{2}$ and could be responsible for the treated water smell and color [19-22].

On the graph $2 b$, we observe a gradual increase of reduction rate of dissolved organic matter. The maximum rate of organic matter removed was $95 \%$ for $\mathrm{E}_{1}$ and $85 \%$ for $E_{2}$. The slight decrease of reduction rate of organic matter beyond the dose of alum equals to $32 \mathrm{mg} / \mathrm{L}$ for $\mathrm{E}_{2}$ sample (Figure 2(b)) it can be due to a restabilization of colloidal particles.

During the water treatment with the aqueous extract of Moringa oleifera, we noted an almost total elimination of microorganisms (Table 6). Escherichia coli, Serratia spp and Enterococus spp were eliminated completely but a reduction of $98.75 \%$ of Klebsiella spp and $97.82 \%$ of Vibrio cholerae were noted. The antimicrobial effect of Moringa is due to the molecule 4 ( $\alpha$-L-Rhamnosyloxy) benzyl isothiocyanate contained in its seeds [23-25].

\subsection{Moringa as Coagulant Aid with Alum}

During the use of Moringa oleifera as a primary coagulant, we obtained that the rate of turbidity reduction is about $60 \%$ for both samples and an enrichment of water treated with organic matter. To improve the quality of treated water, we performed jar-test essays of water samples using Moringa oleifera as coagulant aid with aluminum sulphate. The optimum doses of alum for samples $\mathrm{E}_{1}$ and $\mathrm{E}_{2}(40 \mathrm{mg} / \mathrm{L}$ and $24 \mathrm{mg} / \mathrm{L})$ were reduced by $40 \%$. The amounts of removed alum are gradually replaced by various doses of Moringa oleifera in the proportions of $1 / 6,2 / 6$ to $6 / 6$. The obtained results for the jar tests performed with samples $E_{1}$ and $E_{2}$ were shown in Figure 3.

The doses of alum being constant, the variation of reduction percentages of turbidity and organic matter depends only on Moringa oleifera doses. On the graph 3a, $90 \%$ of turbidity and $96 \%$ of organic matter were removed from the sample $E_{1}$ with a combination of 24 $\mathrm{mg} / \mathrm{L}$ of alum and $12.8 \mathrm{mg} / \mathrm{L}$ of Moringa oleifera. The replacement rate of alum by Moringa oleifera is $4 / 5$. For a dose of alum equal to $40 \mathrm{mg} / \mathrm{L}$ and Moringa oleifera equal to $0 \mathrm{mg} / \mathrm{L}$, the rate of turbidity reduction and organic matter are respectively $88 \%$ and $96 \%$. For sample $\mathrm{E}_{2}$ (Graph $3 \mathrm{~b}$ ), the rates of turbidity reduction and organic matter have reached their maximum value for the combination of alum $14.4 \mathrm{mg} / \mathrm{L}$ and Moringa oleifera 3.2 $\mathrm{mg} / \mathrm{L}$. For this combination, $93 \%$ of initial turbidity and $92 \%$ of initial concentration of organic matter in the sample $\mathrm{E}_{2}$ were eliminated. The $\mathrm{pH}$ remained almost constant during the treatment.

\section{Conclusion}

The groundwater samples analyzed are contaminated by nitrate due to the proximity of septic tanks next to wells for which the waters are sampled. The surface water tur bidities were high in some places and mostly rich of organic matter. The groundwater and surface water presented a microbial pollution of faecal origin. These waters are not potable and cannot be consumed without adequate treatment. The water treatment with Moringa oleifera revealed a substantially reduction of all pathogenic microorganisms present in raw water and could be used in water treatment in rural areas since populations do not have distribution network of drinking water. The

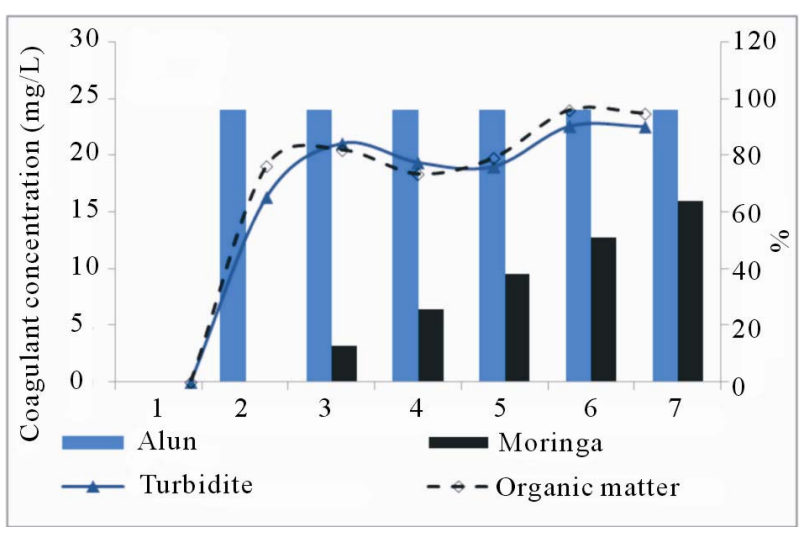

(a)

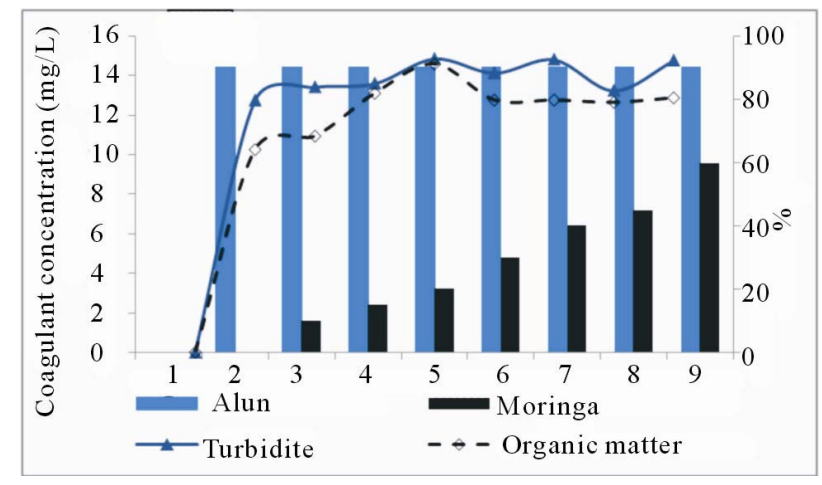

(b)

Figure 3. Variation of removed turbidity and organic matter as a function of coagulant doses $\left(a: E_{1} ; b\right.$ : $\left.E_{2}\right)$. 
treated water with the combined coagulant (Moringa + alum) will be less turbid and dissolved aluminum, organic matter than in pump water.

\section{REFERENCES}

[1] I. M. Adekunle, M. T. Adetunji, A. M. Gbadebo and O. B. Banjoko, "Assessment of Groundwater Quality in a Typical Rural Settlement in Southwest Nigeria," International Journal of Environmental Research and Public Health, Vol. 4, No. 4, 2007, pp. 307-318. doi:10.3390/ijerph200704040007

[2] D. P. Gupta, Sunita and J. P. Saharan, "Physiochemical Analysis of Groundwater of Selected Area of Kaithal City (Haryana), India," Researcher, Vol. 1, No. 2, 2009, pp. $1-5$.

[3] P. T. S. Dhiviyaa, R. T. Venkatesa, L. Punithavathi, S. Karunanithi and A. Bhaskaran, "Groundwater Pollution in the Palar Riverbed near Vellore, Tamil Nadu, India," Indian Journal of Science and Technology, Vol. 4, No. 1, 2011, pp. 19-21.

[4] WHO, "International Standards of Drinking Water," World Health Organization, Geneva, 2004, pp. 55-79.

[5] J. Samia, "Using Moringa oleifera Seeds as Coagulant in Developing Countries," Journal of the American Water Works Association, Vol. 80, No. 6, 1988, pp. 43-50.

[6] N. A. Eman, A. Suleyman, H. M. Muyibi, Salleh, A. M. Zahangir and R. M. Mohd, "Production of Natural Coagulant from Moringa oleifera Seed for Application in Treatment of Low Turbidity Water," Journal of Water Resource and Protection, Vol. 2, 2010, pp. 259-266. doi:10.4236/jwarp.2010.23030

[7] G. Folkard and J. Sutherland, "Development of a Naturally Derived Coagulant for Water and Wastewater Treatment," Water Supply, Vol. 2, No. 5-6, 2002, pp. 8994.

[8] K. Ghebremichael, K. R. Gunaratna, H. Henriksson, H. Brumer and G. Dalhammar, "A Simple Purification and Activity Assay of the Coagulant Protein from Moringa oleifera Seeds," Water Research, Vol. 39, 2005, pp. 2338-2344. doi:10.1016/j.watres.2005.04.012

[9] A. Ndabigengesere and K. S. Narasiah, "Quality of Water Treated by Coagulation Using Moringa oleifera Seeds," Water Research, Vol. 32, No. 3, 1998, pp. 781-791. doi:10.1016/S0043-1354(97)00295-9

[10] M. Suarez, J. M. Entenza, C. Doerries, E. Meyer, L. Bourquin, J. Sutherland, I. Marison, P. Moreillon and N. Mermod, "Expression of a Plant-Derived Peptide Harboring Water-Cleaning and Antimicrobial Activities," Biotechnology and Bioengineering, Vol. 81, No. 1, 2003, pp. 13-20. doi:10.1002/bit.10550

[11] AFNOR, "Qualité de l'eau: Terminologie, Echantillonnage et Evaluation de Méthodes," 2nd Edition, Tome 1, Paris, 1997.

[12] S. H. Lee, S. Lee, K. L. Jang and T. H. Lee, "Microbial Flocculant from Arcuadendron SP-49," Biotechnological Letters, Vol. 17, No. 1, 1995, pp. 95-105. doi:10.1007/BF00134203
[13] T. A. Ahoyo, K. J. Fatombi, M. Boco, T. Aminou and K. L. Dramane, "Impact de la Qualité de l'eau et de l'Assainissement sur la Santé des Enfants en Milieu Périurbain au Bénin: Cas des Zones Sanitaires Savalou-Banté et Dassa-Glazoué," Médecine Tropicale, Vol. 71, No. 3, 2011, pp. 1-5.

[14] N. Ravisankar and S. Poogothai, "A Study of Ground Water Quality in Tsunami Affected Areas of Sirkazhi Taluk, Nagapattinam District, Tamilnadu, India," Scientific of Tsunami Hazards, Vol. 27, No. 1, 2008, pp. 47-55.

[15] J.-Y. Lee and S.-H. Song, "Evaluation of Groundwater Quality in Coastal Areas: Implications for Sustainable Agriculture," Environmental Geology, Vol. 52, No. 7, 2007, pp. 1231-1242. doi:10.1007/s00254-006-0560-2

[16] R. J. Davies-Colley, J. W. Nagels, A. M. Donnison and R. W. Muirhead, "Faecal Contamination of Rural StreamsImplications for Water Quality Monitoring and Riparian Management," 43th Annual Conference of the Water and Wastes Association, Wellington, 19-21 September 2001.

[17] S. C. Edberg, E. W. Rice, R. J. Karlin and M. J. Allen, "Escherichia coli: The Best Biological Drinking Water Indicator for Public Health Protection," Journal of Applied Microbiology, Vol. 88, 2000, pp. S106-S116. doi:10.1111/j.1365-2672.2000.tb05338.x

[18] M. Pritchard, T. Mkandawire and J. G. O'Neill, "Biological, Chemical and Physical Drinking Water Quality from Shallow Wells in Malawi: Case Study of Blantyre, Chiradzulu and Mulanje," Physics and Chemistry of the Earth, Parts $A / B / C$, Vol. 32, No. 15-18, 2007, pp. 1167 1177. doi:10.1016/j.pce.2007.07.013

[19] M. L. Bawa, G. Djanéyé-Boundjou, A. G. Soulémane and I. Kpékpassi, "Etude de la Clarification d'une Eau de Surface par une Substance Naturelle (les Extraits Aqueux de Moringa oleifera Lam): Influence sur la Demande en Chlore,"Physical and Chemical News, Vol. 42, 2008, pp. 133-138.

[20] H. Beltran, J. Sanchez-Martin and K. Ghebremichael, "Comparison of Single-Step and Two-Step Purified Coagulants from Moringa oleifera Seed for Turbidity and DOC Removal,” Bioresource Technology, Vol. 101, 2010, pp. 6259-6261. doi:10.1016/j.biortech.2010.02.072

[21] S. M. Grasiele, B. S. Geovanna, M. S. V. Angelica, N. Leticia, C. C. Karina and B. Rosangela, "Study of Saline Solution on the Extraction of the Moringa oleifera Seed's Active Component for Water Treatment," Water, Air, \& Soil Pollution, Vol. 211, 2010, pp. 409-415. doi:10.1007/s11270-009-0309-0

[22] R. F. Muhammad, W. Nor, P. P. Chan and H. Nasrul, "Mechanism of Turbidity and Hardness Removal in Hard Water Sources by Using Moringa oleifera," Journal of Applied Sciences, Vol. 11, No. 16, 2011, pp. 2947-2963. doi:10.3923/jas.2011.2947.2953

[23] W. Atieno, S. Wagai, P. Arama and J. Ogur, "Antibacterial Activity of Moringa oleifera and Moringa stenopetala Methanol and n-Hexane Seed Extracts on Bacteria Implicated in Water Borne Diseases," African Journal of Microbiology Research, Vol. 5, No. 2, 2011, pp. 153-157.

[24] J. Raheela, S. Muhammad, J. Amer and A. Muhammad, "Microscopic Evaluation of the Antimicrobial Activity of 
Seed Extracts of Moringa oleifera," Pakistan Journal of Botany, Vol. 40, No. 4, 2008, pp. 1349-1358.

[25] M. Pritchard, T. Craven, T. Mkandawire, A. S. Edmondson and J. G. O'Neill, "A Comparison between Moringa oleifera and Chemical Coagulants in the Purification of
Drinking Water-An Alternative Sustainable Solution for Developing Countries," Physics and Chemistry of the Earth, Vol. 35, No. 13-14, 2010, pp. 798-805. doi:10.1016/i.pce.2010.07.014 